\title{
The Global Atmospheric Environment for the Next Generation
}

F. Dentener, D. Stevenson, K. Ellingsen, T. van Joije, M. Schultz, M. Amann, C. Atherton, N. Bell, D. Bergmann, I. Bey, L. Bouwman, T. Butler, J. Cofala, B. Collins, J. Drevet, R. Doherty, B. Eickhout, H. Eskes, A. Fiore, M. Gauss, D. Hauglustaine, L. Horowitz, I. S. A. Isaksen, B. Josse, M. Lawrence, M. Krol, J. F. Lamarque, V. Montanaro, J. F. Muller, V. H. Peuch, G. Pitari, J. Pyle, S. Rast, J. Rodriguez, M. Sanderson, N. H. Savage, D. Shindell, S. Strahan, S. Szopa, K. Sudo, R. Van Dingenen, O. Wild, G. Zeng

December 8, 2005

Environmental Science and Technology 
This document was prepared as an account of work sponsored by an agency of the United States Government. Neither the United States Government nor the University of California nor any of their employees, makes any warranty, express or implied, or assumes any legal liability or responsibility for the accuracy, completeness, or usefulness of any information, apparatus, product, or process disclosed, or represents that its use would not infringe privately owned rights. Reference herein to any specific commercial product, process, or service by trade name, trademark, manufacturer, or otherwise, does not necessarily constitute or imply its endorsement, recommendation, or favoring by the United States Government or the University of California. The views and opinions of authors expressed herein do not necessarily state or reflect those of the United States Government or the University of California, and shall not be used for advertising or product endorsement purposes. 


\title{
The global atmospheric environment for the next generation
}

\author{
F.Dentener ${ }^{1}$, D.Stevenson ${ }^{2}$, K.Ellingsen ${ }^{3}$, T.van Noije ${ }^{4}$, M.Schultz $^{18}$, M.Amann ${ }^{5}$, \\ C.Atherton ${ }^{12}$, N.Bell ${ }^{9}$, D.Bergmann ${ }^{12}$, I.Bey ${ }^{8}$, L.Bouwman ${ }^{6}$, T.Butler ${ }^{14}$, J.Cofala $^{5}$, \\ B.Collins ${ }^{20}$, J.Drevet ${ }^{8}$, R.Doherty ${ }^{2}$, B.Eickhout ${ }^{6}$, H.Eskes ${ }^{4}$, A.Fiore ${ }^{16}$, M.Gauss $^{3}$, \\ D.Hauglustaine $^{13}$, L.Horowitz ${ }^{16}$, I.S.A. Isaksen ${ }^{3}$, B.Josse ${ }^{15}$, M.Lawrence ${ }^{14}$, M.Krol $^{1}$, \\ J.F.Lamarque ${ }^{17}$, V.Montanaro ${ }^{21}$, J.F.Müller ${ }^{11}$, V.H.Peuch ${ }^{15}$, G.Pitari ${ }^{21}$, J.Pyle ${ }^{19}{ }^{\text {,S.Rast }}{ }^{18}$, \\ J.Rodrigue $^{22}$, M.Sanderson ${ }^{20}$, N.H.Savage ${ }^{19}$, D.Shindell ${ }^{9}$, S.Strahan ${ }^{10}$, S.Szopa ${ }^{13}$, \\ K.Sudo ${ }^{7}$, R.Van Dingenen ${ }^{1}$,O.Wild ${ }^{7}$, G.Zeng ${ }^{19}$. \\ 1. Joint Research Centre, Institute for Environment and Sustainability, Ispra, Italy. \\ 2. University of Edinburgh, School of Geosciences, United Kingdom. \\ 3. University of Oslo, Department of Geosciences, Norway. \\ 4. Royal Netherlands Meteorological Institute (KNMI), De Bilt, the Netherlands. \\ 5. IIASA, International Institute for Applied Systems Analysis, Laxenburg, Austria. \\ 6. Netherlands Environmental Assessment Agency (RIVM/MNP), Bilthoven, The \\ Netherlands. \\ 7. Frontier Research Center for Global Change, JAMSTEC, Yokohama, Japan. \\ 8. Swiss Federal Institute of Technology (EPFL), Lausanne, Switzerland. \\ 9. NASA-Goddard Institute for Space Studies, New York, USA. \\ 10. Goddard Earth Science \& Technology Center (GEST), Maryland, USA. \\ 11. Belgian Institute for Space Aeronomy, Brussels, Belgium. \\ 12. Lawrence Livermore National Laboratory, Atmospheric Science Division, Livermore, \\ USA. \\ 13. CEA/CNRS, Laboratoire des Sciences du Climat et de l'Environnement, Gif-sur- \\ Yvette, France. \\ 14. Max Planck Institute for Chemistry, Mainz, Germany. \\ 15. Meteo-France, CNRM/GMGEC/CATS, Toulouse, France. \\ 16. NOAA GFDL, Princeton, NJ, USA. \\ 17. National Center of Atmospheric Research, Atmospheric Chemistry Division, \\ Boulder, CO, USA. \\ 18. Max Planck Institute for Meteorology, Hamburg, Germany. \\ 19. University of Cambridge, Centre of Atmospheric Science, United Kingdom. \\ 20. Met Office, Exeter, United Kingdom. \\ 21. Università L'Aquila, Dipartimento di Fisica, Italy. \\ 22. University of Miami/NASA-Goddard Space Flight Center
}

Submitted ES\&T, 01.12.2005

\begin{abstract}
Air quality, ecosystem exposure to nitrogen deposition, and climate change are intimately coupled problems: we assess changes in the global atmospheric environment between 2000 and 2030 using twenty-five state-of-the-art global atmospheric chemistry models and three different emissions scenarios. The first (CLE) scenario reflects implementation of current air quality legislation around the world, whilst the second (MFR) represents a
\end{abstract}


more optimistic case in which all currently feasible technologies are applied to achieve maximum emission reductions. We contrast these scenarios with the more pessimistic IPCC SRES A2 scenario. Ensemble simulations for the year 2000 are consistent among models, and show a reasonable agreement with surface ozone, wet deposition and $\mathrm{NO}_{2}$ satellite observations. Large parts of the world are currently exposed to high ozone concentrations, and high depositions of nitrogen to ecosystems. By 2030, global surface ozone is calculated to increase globally by $1.5 \pm 1.2 \mathrm{ppbv}$ (CLE), and $4.3 \pm 2.2 \mathrm{ppbv}$ (A2). Only the progressive MFR scenario will reduce ozone by $-2.3 \pm 1.1 \mathrm{ppbv}$. The CLE and A2 scenarios project further increases in nitrogen critical loads, with particularly large impacts in Asia where nitrogen emissions and deposition are forecast to increase by a factor of 1.4 (CLE) to 2 (A2). Climate change may modify surface ozone by $-0.8 \pm 0.6$ ppbv, with larger decreases over sea than over land. This study shows the importance of enforcing current worldwide air quality legislation, and the major benefits of going further. Non-attainment of these air quality policy objectives, such as expressed by the SRES-A2 scenario, would further degrade the global atmospheric environment.

\section{Introduction}

Emissions of reactive nitrogen, i.e. nitrogen oxides $\left(\mathrm{NO}_{\mathrm{x}}=\mathrm{NO}+\mathrm{NO}_{2}\right)$, generated in the burning of fossil- and bio-fuels, and ammonia $\left(\mathrm{NH}_{3}\right)$ volatilized from agricultural processes, cause a number of environmental problems. Ozone $\left(\mathrm{O}_{3}\right)$ is formed in the presence of $\mathrm{NO}_{\mathrm{x}}$, methane $\left(\mathrm{CH}_{4}\right)$, carbon monoxide $(\mathrm{CO})$ and hydrocarbons. $\mathrm{O}_{3}$ is an important greenhouse gas and is also toxic to humans, animals and plants. The IPCC Third Assessment Report (1) recognized the intertwined role of $\mathrm{CH}_{4}$ and conventional air pollutant emissions for climate and air quality. In particular, an evaluation of the highemissions IPCC SRES A2 emissions scenario showed global mean surface $\mathrm{O}_{3}$ increases of about 5 ppbv by 2030 and 20 ppbv by 2100 (2). Another associated adverse impact of the enhanced emissions of $\mathrm{NO}_{\mathrm{x}}$ and $\mathrm{NH}_{3}$ is the increased long-range transport and deposition of nitrogen, leading to damaging eutrophication and acidification of ecosystems and loss of biodiversity $(3,4)$.

In this work we focus on climate change, air quality, and ecosystem exposure to nitrogen deposition for the year 2030. We use a new set of emission scenarios for $\mathrm{CH}_{4}, \mathrm{NO}_{\mathrm{x}}, \mathrm{NH}_{3}$, $\mathrm{CO}, \mathrm{SO}_{2}$ and non-methane volatile organic compounds (NMVOC) recently developed at IIASA (International Institute for Applied Systems Analysis) and described by (5). The scenarios differ substantially from the previous SRES (6) scenarios. In the last few years increasing air pollution in developing countries has become a public concern $(5$, and references therein). As a consequence many of the major rapidly developing countries in Asia and Latin America have issued legislation on state-of-the-art emission controls. Upon implementation, these regulations will significantly cap the air pollution emissions at the regional and global scales. This is the basis of our CLE (Current LEgislation) scenario. Further, we evaluate the effects of the emissions of a MFR (Maximum technologically Feasible Reduction) scenario, and contrast it with the pessimistic SRES A2 scenario. Both CLE and MFR are based on economic and energy use projections according to the moderate SRES B2 scenario. These emission scenarios were used by 25 
global atmospheric chemistry-transport models (CTMs) driven by re-analyzed meteorological fields or general circulation models (GCMs), run by groups in Europe, the United States, and Japan. Although some models share some common sub-components, the ensemble of model results is sufficiently broad to estimate uncertainties resulting from the various assumptions in the transport models. The models performed baseline (year 2000) and 2030 scenarios, all using a fixed meteorology based on the year 2000; whereas a subset of models repeated the 2030 CLE scenario, but with a changed climate. In this paper we give an integrative overview of the findings; other publications (7-10) present more detailed results from this large model exercise.

\section{Methods}

Up to five simulations were performed by each model (Table 1). B2000 evaluated the reference year 2000, whilst CLE, MFR, and A2 assessed the year 2030. CTMs used the meteorological year 2000. GCMs performed 5-10 years of simulations, using a climate appropriate for the time period 1995-2004. To evaluate the impacts of climate change, an additional simulation (CLE2030c) was computed by nine of the GCM-driven models, using a climate appropriate for 2030. Most modelers applied the IS92a climate scenario associated with a global mean surface warming of about $0.7 \mathrm{~K}$ between 2000 and 2030 . Global emissions of $\mathrm{NO}_{x}, \mathrm{CO}, \mathrm{NMVOC}$, and $\mathrm{CH}_{4}$ (Table 1) were generated by IIASA, and spatially distributed using the EDGAR3.2 database, as described in and references therein. $\mathrm{NH}_{3}$ emissions were generated by RIVM IMAGE model

(http://arch.rivm.nl/image ). To avoid excessive spin-up times for equilibration of $\mathrm{CH}_{4}$ we prescribed global $\mathrm{CH}_{4}$ volume mixing ratios instead of emissions [Table 1], using consistent values from earlier transient simulations for 1990-2030 described in $(5,11)$. In electronic supplement Table ES1 we present the 25 participating models, including characteristics of their resolution, chemistry and transport parameterizations. Compared to the earlier modeling exercises $(2,12)$ twice as many models participated in this study; model complexity (inclusion of NMVOC chemistry), and resolutions have greatly improved: almost half of the models had horizontal resolutions of $2^{\circ}-3^{\circ}$ or better, and almost of the other models had resolutions around $4^{\circ}-5^{\circ}$. Further information on the model experiment can be found on http://www2.nilu.no/farcry_accent.

\section{Results}

\section{Surface ozone increases}

In Figure 1a-1d we display the annual average $\mathrm{O}_{3}$ and $\mathrm{O}_{3}$ differences at the earth surface calculated from all models for B2000, CLE, MFR, and A2 in 2030. The impact of climate change (CLE2030c) is given in Figure 1e. Figure 1a shows that calculated annual average surface $\mathrm{O}_{3}$ varies between 40-50 ppbv over large parts of N. America, S. Europe, and Asia. Background values ranging between 15-25 ppbv are found in large parts of the $S$. Hemisphere (SH). Average surface concentrations are 33.7 $\pm 3.8,23.7 \pm 3.7$ and $28.7 \pm$ $3.6 \mathrm{ppbv}$ (Table 2), for the N. Hemisphere (NH), SH, and world, respectively. In Figure 1a we also give averaged measurements for the year 2000, taken from the WMO-GAW World Data Centre for surface ozone, EMEP/AIRBASE in Europe; and CASTNet in the 
United States. Measurements for India, China, and Africa are from various scientific studies (13-16). Our analysis reveals that our mean model results agree within 5 ppbv with measurements in the USA, China, and Central Europe, and may overestimate the measured annual average with 10-15 ppbv in Africa, India and the Mediterranean. The variability among the annual model results was of the order $10-30 \%$.

The CLE scenario (Figure 1b, Table 2) would approximately stabilize $\mathrm{O}_{3}$ in 2030 at 2000 levels in parts of N. America, Europe and Asia. However, $\mathrm{O}_{3}$ may increase by more than $10 \mathrm{ppbv}$ in areas anticipated to experience large increases of transport and power generation related emissions (e.g. India). Background $\mathrm{O}_{3}$ increases by $2-4 \mathrm{ppbv}$ in the tropical and mid-latitude $\mathrm{NH}$, related to the interaction of the increasing concentrations of $\mathrm{CH}_{4}$ and the worldwide increase of emissions of $\mathrm{NO}_{x}, \mathrm{CO}$, and NMVOC. The increases are most consistently predicted in Asia; whereas the ensemble predictions are not robust (large standard deviations) in North and South America, Southern Africa and the Middle East. A cleaner future is possible, if all currently available technologies are used to abate $\mathrm{O}_{3}$ precursor emissions. In this MFR case (Figure 1c; Table 2) $\mathrm{O}_{3}$ reduces by 5-10 ppbv relative to the present situation in the regions of main pollution. The models are consistent in their prediction of the ozone reductions with relative standard deviations around $30-40 \%$. Finally, consistent with previous studies (2), in the A2 scenario (Figure 1d), annual average surface $\mathrm{O}_{3}$ increase sy $4.3 \mathrm{ppbv}$ worldwide and by $5-15 \mathrm{ppbv}$ in Latin America, Africa and Asia.

How is climate change expected to influence these $\mathrm{O}_{3}$ changes? The average results from 9 models for the CLE2030c scenario indicate that climate change may reduce surface $\mathrm{O}_{3}$ by $1-2$ ppbv over the oceans, and by 0.5 to $1 \mathrm{ppbv}$ over the continents. We find that the climate change related processes affecting surface $\mathrm{O}_{3}$ were the regional and global increase of temperature and water vapor, tending to decrease surface $\mathrm{O}_{3}$, particularly in the cleanest regions, and the increased influx of stratospheric $\mathrm{O}_{3}$ into the troposphere, increasing free tropospheric and surface $\mathrm{O}_{3}$. Note that many feedbacks, e.g. from natural emission changes, were generally not included in the models. We further note that the variability in the calculated climate induced ozone perturbations is large [Table 2], associated with the differences of individual climate model simulations.

What is the effect on ozone air quality? Several regulatory $\mathrm{O}_{3}$ air quality limits, with threshold values of 60-80 ppbv, are currently employed in Europe, the USA and Japan. The World Health Organization (WHO) re-analyzed epidemiological studies of $\mathrm{O}_{3}$ related health effects, and recommend the air quality index called SOMO35 (http://www.unece.org/env/documents/2004/eb/wg1/eb.air.wg1.2004.11.e.pdf). SOMO35 is based on the exceedance over 35 ppbv "background level" of the daily maximum of an 8 -hour running average ozone volume mixing ratio $\left(\mathrm{MaxO}_{3}\right)$ :

$$
\sum_{d a y=1}^{d a y=365 / 366}\left[\left(\mathrm{MaxO}_{3}-35 p p b v, \mathrm{MaxO}_{3}>35 p p b v\right),\left(0, \mathrm{MaxO}_{3} \leq 35 \mathrm{ppbv}\right)\right]
$$


In contrast to other air quality limits, $\mathrm{SOMO} 35$ considers $\mathrm{O}_{3}$ toxicity at lower concentrations; and is more suited to assess the effect of large scale changes of ozone background concentrations. Figure 2 gives the SOMO35 for scenario S1-S4, and in Table 2 we give a regional analysis of SOMO35. Ellingsen et al. (8) show that a SOMO35 of $3000 \mathrm{ppb}$ days is consistent with air quality limits currently in use in North America and Europe. According to our model calculations SOMO35 is exceeded in large parts of the world in the year 2000; most notably in the United States, the Middle East, and South Asia (India). In these regions most models consistently compute SOMO35 in excess of 3000 ppb.days. Only in the MFR scenario ozone will be close to the WMO airquality limit. The large scale regional and annual averaged ozone and SOMO35 appear to be highly correlated with a correlation coefficient of $r=0.99$; this high correlation follows from the fact that already at present background ozone is close to the $35 \mathrm{ppbv}$ threshold.

\section{Nitrogen deposition}

In Figure 3a-d we give the calculated $\mathrm{NO}_{\mathrm{y}}$ total deposition averaged for 22 models in 2000, CLE, MFR, and A2 2030. Figure 3e gives the total reactive nitrogen $\left(=\mathrm{NO}_{\mathrm{y}}+\mathrm{NH}_{\mathrm{x}}\right)$ deposition in the year 2000, showing the importance of $\mathrm{NHx}$ deposition. It is currently thought that $1000 \mathrm{mgNm}^{-2} \mathrm{yr}^{-1}$ is a threshold ("critical load"), above which changes in sensitive natural ecosystems may occur $(4,17)$. So far most studies have focused on the effects of $\mathrm{NO}_{\mathrm{y}}$ deposition (18), since it is intimately associated with $\mathrm{O}_{3}$ formation. Our results indicate that accounting for $\mathrm{NH}_{\mathrm{x}}$ deposition, related to animal and food production systems, may double the deposition from $\mathrm{NO}_{\mathrm{y}}$ alone. The resulting total Nitrogen $\left(\mathrm{NO}_{\mathrm{y}}\right.$ and $\mathrm{NH}_{\mathrm{x}}$ ) deposition exceeds $2000 \mathrm{mgNm}^{-2} \mathrm{yr}^{-1}$ in extended parts of the world, including biodiversity hotspots. To date, the consequences for biodiversity and ecosystem health have only been studied for temperate regions, but it has been suggested that increased nitrogen deposition will play an important future role in the decrease of plant diversity worldwide (19). A comparison of the corresponding calculated wet deposition fluxes with measurements in USA, Europe, S.E. Asia, Africa and S. America, yields agreement within a factor of two for 70-80 \% of the measurement stations (see EF). Exceptions are Asia where the models strongly underestimate $\mathrm{NO}_{\mathrm{y}}$ deposition by up to $60 \%$, and $\mathrm{S}$. America, where almost no measurement data were found. In 2030, considering the CLE scenario $\mathrm{NO}_{\mathrm{y}}$ deposition decreases in Europe, is near-constant in N. America, and strongly increases in Asia. $\mathrm{NH}_{\mathrm{x}}$ depositions increase almost everywhere. Our clean MFR scenario, which was evaluated only for $\mathrm{NO}_{\mathrm{y}}$, considerably improves this situation, with $\mathrm{NO}_{\mathrm{y}}$ deposition almost everywhere below $500 \mathrm{mgNm}^{-2} \mathrm{yr}^{-1}$. In contrast, the $\mathrm{A} 2$ scenario in the year 2030 leads to extended regions exposed to $\mathrm{NO}_{\mathrm{y}}$ deposition larger than 1000 $\mathrm{mgNm}^{-2} \mathrm{yr}^{-1}$.

\section{Satellite observations of $\mathrm{NO}_{2}$ columns}

Recent satellite observations allow us to evaluate nitrogen pollution on near global scales. For the year 2000, the GOME instrument on-board of the ERS-2 satellite, provides a unique opportunity to compare model calculated $\mathrm{NO}_{2}$ columns with measurements. We compare model $\mathrm{NO}_{2}$ column output at the satellite overpass time (10:30 LT), taking into account sampling issues, and uncertainties in retrievals. Daily tropospheric $\mathrm{NO}_{2}$ column 
densities were calculated by 17 different models; uncertainties in the retrievals are quantified by using retrieval products from three different groups: KNMI/BIRA-IASB (20), University of Bremen (21), and an update of the Dalhousie/SAO retrieval (22), excluding uncertain retrievals at high latitudes. Low tropospheric $\mathrm{NO}_{2}$ columns of $<1$ $10^{15}$ moleccm $^{-2}$ are calculated and observed by GOME in marine regions. Over the continents, three regions of dominant $\mathrm{NO}_{2}$ pollution are found in N. America, W.Europe, and China, coinciding with the regions of high emissions. These regions are also indicated in the average model; but the averaged model maxima of 6-8 $10^{15}$ moleccm $^{-2}$ clearly underestimate the GOME observed values, which exceed $1010^{15}$ moleccm $^{-2}$. The difference of models and measurements is particularly pronounced over the rapidly developing parts of Eastern China and South Africa, indicating that the assumed $\mathrm{NO}_{\mathrm{x}}$ emissions may be unrealistically low in these regions. In regions dominated by biomass burning, such as in Africa and South America, the models tend to overestimate the observed seasonal cycle.

We note that the discrepancy in $\mathrm{NO}_{2}$ column in e.g. North America and Europe does not seem consistent with the general agreement in $\mathrm{NO}_{3}$ wet deposition. In the rapidly developing parts of China and Southern Africa, the model-satellite discrepancy indicates an underestimate of $\mathrm{NO}$ emissions, consistent with underestimates of $\mathrm{N}$-deposition, but not corroborated by similar discrepancies in surface ozone. One important finding, however, is that the differences of the GOME retrievals are in many instances as large as the spread in model results, meaning that in only a few cases(i.e. in China) robust statements on under prediction of NO emissions can be made.

\section{The present and future atmospheric environment}

The results from 25 state-of-the-art atmospheric chemistry transport and climate models regarding changes in surface $\mathrm{O}_{3}$, and deposition of nitrogen are for the year 2000 broadly consistent with measurements of current day $\mathrm{O}_{3}, \mathrm{NO}_{2}$ columns, and nitrogen deposition, with largest discrepancies in the developing regions of India, Africa, and S.E. Asia. Most models indicate that already in the year 2000, the most recent WHO recommended air quality standard SOMO35 is exceeded over large regions. We considered 3 scenarios for 2030. In the CLE scenario this situation is aggravated in parts of Asia (most notably in India with large growth in the transport sector), whereas the MFR scenario provides a cleaner alternative for $\mathrm{O}_{3}$. Our model results indicate that the undesirable SRES A2 scenario would lead to large problems in 2030 with attaining any air quality standard in most industrialized parts of the world. We also show that $\mathrm{NO}_{\mathrm{y}}$ and $\mathrm{NH}_{\mathrm{x}}$ deposition are already at present above the critical nitrogen loads, resulting in eutrophication and decrease of biodiversity. These deposition fluxes are expected to increase further considering the CLE and A2 scenarios. The same emissions that worsen air quality and nitrogen deposition also have a substantial impact on climate. Stevenson et al. (10) show that the sum of the $\mathrm{O}_{3}$ and $\mathrm{CH}_{4}$ radiative forcings, in case of CLE and $\mathrm{A} 2$, contributes $22 \%-28 \%$ to the forcings of $\mathrm{CO}_{2}$ alone. Only introduction of stringent $\mathrm{NO}_{\mathrm{x}}, \mathrm{CO}$, NMVOC, and $\mathrm{CH}_{4}$ abatement technologies (MFR) prevents further increases in the forcings of $\mathrm{O}_{3}$ and $\mathrm{CH}_{4}$. Integrated analysis of the impacts, and of the cost-benefits of 
reducing $\mathrm{NO}_{x}, \mathrm{CO}, \mathrm{NMVOC}$, and $\mathrm{CH}_{4}$ emissions $(5,23,24)$ is needed to guarantee a cleaner atmospheric environment for the next generation.

\section{Acknowledgements}

This model exercise was organized under the umbrella of the EC FP6 Network of Excellence ACCENT.

This work was performed under the auspices of the U.S. Department of Energy by University of California, Lawrence Livermore National Laboratory under contract W-7405-Eng-48. 


\section{References}

(1) Prather, M.; Ehhalt, D.; Dentener, F.; Derwent, R.; Dlugokencky, E.; Holland, E.; Isaksen, I.; Katima, J.; Kirchhoff, V.; Matson, P.; Midgley, P.; Wang, M. In Climate Change 2001, The scientific basis: Contribution of working group I to the Third assessment report of the Intergovernmental Panel on Climate; Houghton, J. T., Ding, Y., Griggs, D. J., Noguer, M., Linden, P. J. v. d., Dai, X., Maskell, K., Johnson, C. A., Eds.; Cambridge University Press: Cambridge, United Kingdom and New York, NY, US, 2001; p 881

(2) Prather, M.; Gauss, M.; Berntsen, T. K.; Isaksen, I.; Sundet, J.; Bey, I.; Brasseur, G.; Dentener, F.; Derwent, R.; Stevenson, D. S.; Grenfell, L.; Hauglustaine, D.;

Horowitz, L. W.; Jacob, D.; Mickley, L. J.; Lawrence, M. G.; Kuhlman, R. v.; Muller, J.F.; Pitari, G.; Rogers, H.; Johnson, M.; Pyle, J. A.; Law, K. S.; Weele, M. v.; Wild, O. Fresh air in the 21st century. Geophys. Res. Lett 2003, 30, 72-72-74.

(3) Stevens, C. J.; N.B. Dise; J.O. Mountford; Gowing, D. J. Impacts of nitrogen deposition on species richness of grassland. Science 2004, 303, 1876-1879.

(4) Galloway, J. M.; F.J. Dentener; D.G. Capone; E.W. Boyer; R.W. Howarth; S.P. Seitzinger; G.P. Asner; C. Cleveland; P. Green; E. Holland; D.M. Karl; A.F. Michaels; J.H. Porter; A. Townsend; Charles, V. Nitrogen Cycles: Past, Present and Future. Biogeochemistry 2004, 70, 153-226.

(5) Dentener, F.; D. Stevenson; J. Cofala; R. Mechler; M. Amann; P. Bergamaschi; F. Raes; Derwent, R. The impact of air pollutant and methane emission controls on tropospheric ozone and radiative forcing: CTM calculations for the period 1990-2030. Atmospheric Chemistry and Physics 2005, 5, 1731-1755, SREF-ID:1680-7324/ap/20051735-1731.

(6) Nakicenovic, N.; Alcamo, J.; Davis, G.; De Vries, B.; Fenhann, J.; Gaffin, S.; Gregory, K.; Grübler, A.; Jung, T. Y.; Kram, T.; Lebre La Rovere, E.; Michaelis, L.; Mori, S.; Morita, T.; Pepper, W.; Pitcher, H.; Price, L.; Riahi, K.; Roehrl, A.; Rogner, H. H.; Sankovski, A.; Schlesinger, M.; Priyadarshi Shukla, P.; Steven Smith, S.; Robert Swart, R.; Van Rooijen, S.; Victor, N.; Dadi, Z.; Cambridge University press: Cambridge, United Kingdom and New York, USA, 2000; p 599 p.

(7) Dentener, F.; etal. Nitrogen and Sulphur Deposition on regional and global scales: a multi-model evaluation. Global Biogeochemical Cycles 2005, in preparation.

(8) Ellingsen, K.; etal Ozone air quality in 2030: a multi model assessment of risks for health and vegetation. Journal of Geophysical Research 2005, in preparation.

(9) van Noije, T.; etal Multi-model ensemble simulations of tropospheric NO2 compared with GOME retrievals for the year 2000. Journal Geophysical Research $\mathbf{2 0 0 5}$, in preparation.

(10) Stevenson, D. S.; Dentener, F. J.; Schultz, M. G.; Ellingsen, K.; Van Noije, T. P. C.; Wild, O.; Zeng, G.; M. Amann; Atherton, C. S.; Bell, N.; Bergmann, D. J.; Bey, I.; Butler, T.; Cofala, J.; Collins, W. J.; Derwent, R. G.; Doherty, R. M.; Drevet, J.; Eskes, H. J.; Fiore, A.; Gauss, M. A.; Hauglustaine, D. A.; Horowitz, L. W.; Isaksen, I. S. A.; Krol, M. C.; Lamarque, J. F.; Lawrence, M. G.; Montanero, V.; Müller, J. F.; Pitari, G.; Prather, M. J.; Pyle, J. A.; Rast, S.; Rodriguez, J. M.; Sanderson, M. G.; Savage, N. H.; Shindell, D. T.; Strahan, S. E.; Sudo, K.; Szopa, S. Multi-model ensemble simulations of 
present-day and near-future tropospheric ozone. Journal Geophysical Research $\mathbf{2 0 0 5}$, accepted.

(11) Stevenson, D.; R. Doherty; M. Sanderson; C. Johnson; B. Collins; Derwent, D. Impacts of climate change and variability on tropospheric ozone and its precursors. Faraday Discuss 2005, 130, 1-17.

(12) Gauss, M., G. Myhre, G. Pitari, M. J. Prather, I. S. A. Isaksen, T. K. Berntsen, G. P. Brasseur, F. J. Dentener, R. G. Derwent, ; D. A. Hauglustaine, L. W. H., D. J. Jacob, M. Johnson, K. S. Law, L. J. Mickley, J.-F. Müller, P.-H. Plantevin, J. A. Pyle, H. L. Rogers, D. S. Stevenson, J. K. Sundet, M. van Weele, ; Wild, O. Radiative forcing in the 21 st century due to ozone changes in the troposphere and the lower stratosphere.

J.Geophys. Res. 2003, 108 (D9), 4292, doi:4210.1029/2002JD002624.

(13) Zunckel, M.; K. Venjonoka; J.J. Pienaar; E.G. Brunke; O. Pretorius; A.

Koosialee; A. Raghunandan; Tienhoven, A. M. v. Surface ozone over southern Africa, synthesis of monitoring results during the cross border Air Pollution Impact Assessment project. Atmos Environ. 2004, 38, 6139-6147.

(14) Carmichael, G. R.; Ferm, M.; Thongboonchoo, N.; Woo, J.-H.; Chan, L. Y.; Murano, K.; Viet, P. H.; Mossberg, C.; Bala, R.; Boonjawat, J.; Upatum, P.; Mohan, M.; Adhikary, S. P.; Shrestha, A. B.; Pienaar, J. J.; Brunke, E. B.; Chen, T.; Jie, T.; Guoan, D.; Peng, L. C.; Dhiharto, S.; Harjanto, H.; Jose, A. M.; Kimani, W.; Kirouane, A.; Lacaux, J.; Richard, S.; Barturen, O.; Cerda, J. C.; Athayde, A.; Tavares, T.; Cotrina, J. S.; Bilici, E. Measurements of sulfur dioxide, ozone and ammonia concentrations in Asia, Africa, and South America using passive samplers. Atm. Env. 2003, 37, 1293-1308.

(15) Naja, M.; Lal, S. Surface ozone and precursor gases at Gadanki (13.5 N, 79.2 E) a tropical rural site in India. Journal Geophysical Research 2002, 107, 4179, DOI: 4110.1029/2001JD000357.

(16) Naja, M.; S. Lal; Chand, D. Diurnal and seasonal variabilities in surface ozone at a high altitude site Mt Abu (24.6 N, 72,7 E, 160 ma asl) in India. Atm. Env. 2003, 37, 4205-4215.

(17) Bobbink, R.; M. Hornung; J.M. Roelofs The effects of air-borne pollutants on species diversity in natural and semi-natural European vegetation. Journal of Ecology 1998, 86, 717-738.

(18) Holland, E. A.; B.H. Brasswell; J.F. Lamarque; A. Townsend; J. Sulzman; J.F.Muller; F. Dentener; G.Brasseur; H. Levy II; J.E. Penner; Roelofs, G. J. Variations in the predicted spatial distribution of atmospheric nitrogen deposition and their impact on carbon uptake by terrestial ecosystems. J. Geophys. Res. 1997, 102, 15849-15866. (19) Sala, O. E., F.S. Chapin III, J.J. Armesto, R. Berlow, J. Bloomfield, R. Dirzo, E. Huber-Sanwald, L.F. Huenneke, R.B. Jackson, A. Kinzig, R. Leemans, D. Lodge, H.A. Mooney, M. Oesterheld, N.L. Poff, M.T. Sykes, B.H. Walker, M. Walker, and D.H. Wall, Global biodiversity scenarios for the year 2100. Science 2000, 87, 1770-1774.

(20) Boersma, K. F.; H.J. Eskes; Brinksma, E. J. Error analysis for tropospheric NO2 retrieval from space. J. Geophys. Res. 2004, 109, doi:10.1029/2003JD003962.

(21) Richter, A.; Burrows, J. P. Retrieval of tropospheric NO2 from GOME measurements. Adv. Space Res. 2002, 29, 1673-1683.

(22) Martin, R. V.; K. Chance; D.J. Jacob; T.P. Kurosu; R.J.D. Spurr; E. Bucsela; J.F. Gleason; P.I. Palmer; I. Bey; A.M. Fiore; Q. Li; R.M. Yantosca; Koelemeijer, R. B. A. 
An improved retrieval of tropospheric nitrogen dioxide from GOME. J. Geophys. Res. 2002, 107, 4437, 4410.1029/2001JD001027.

(23) Fiore, A. M.; Jacob, D. J.; Field, B. D.; D. G. Streets; S. D. Fernandes; Jang, C. Linking ozone pollution and climate change: The case for controlling methane. Geophys. Res. Lett 2002, 29, 25-21/25-24, doi:10.1029/2002GL015601.

(24) West, J. J.; Fiore, A. M. Management of Tropospheric Ozone by Reducing Methane Emissions. Environ. Sci. Technol. 2005, E39(13), 4685-4691, doi:4610.1021/es048629f. 
Table 1. Overview of simulations, prescribed methane volume mixing ratios and global anthropogenic emissions of $\mathrm{CO}, \mathrm{NMVOC}, \mathrm{SO}_{2}$ and $\mathrm{NH}_{3}$. Emissions in Tg Full Molecular Weight /year.

\begin{tabular}{|l|l|l|l|l|l|l|l|l|}
\hline \multicolumn{1}{|c|}{ Simulation } & \multicolumn{1}{|c|}{ Meteorology } & \multicolumn{1}{|c|}{ Description } & $\begin{array}{l}\mathbf{C H} \\
\mathbf{p p b v}\end{array}$ & $\mathbf{C O}$ & $\mathbf{N M V O C}$ & $\begin{array}{l}\mathbf{N O}_{\mathbf{x}} \\
\left(\mathbf{N O} \mathbf{O}_{2}\right.\end{array}$ & $\mathbf{S O}_{2}$ & $\mathbf{N H}_{\mathbf{3}}$ \\
\hline S1-B2000 & $\begin{array}{l}\text { CTM 2000 } \\
\text { GCM SSTs 1990s }\end{array}$ & Baseline. & 1760 & 977 & 147.1 & 124.8 & 111.1 & 64.8 \\
\hline S2-CLE/CLEc & $\begin{array}{l}\text { CTM 2000 } \\
\text { GCM SSTs 1990s }\end{array}$ & $\begin{array}{l}\text { IIASA CLE 2030. Current } \\
\text { Legislation scenario. }\end{array}$ & 2088 & 904.1 & 145.5 & 141.1 & 117.6 & 84.8 \\
\hline S3-MFR & $\begin{array}{l}\text { CTM 2000 } \\
\text { GCM SSTs 1990s }\end{array}$ & $\begin{array}{l}\text { IIASA MFR 2030 } \\
\text { Maximum Feasible } \\
\text { Reduction scenario }\end{array}$ & 1760 & 728.7 & 104.4 & 76.0 & 35.8 & 84.8 \\
\hline S4-A2 & $\begin{array}{l}\text { CTM 2000 } \\
\text { GCM SSTs 1990s }\end{array}$ & $\begin{array}{l}\text { SRES A22030, the most } \\
\text { 'pessimistic' IPCC SRES } \\
\text { scenario }\end{array}$ & 2163 & 1268.2 & 206.7 & 206.7 & 202.3 & 89.2 \\
\hline S5c-CLE2030c & only GCM SSTs & $\begin{array}{l}\text { IIASA CLE 2030 + } \\
\text { Climate Change }\end{array}$ & 2012 & 904.1 & 145.5 & 141.1 & 117.6 & 84.8 \\
\hline
\end{tabular}


Table 2: Area weighted regional and global annual mean surface ozone [ppbv] and in Italics SOMO35 [ppbv days] in 2000 and increases for various scenarios at selected regions. Regions are defined according to IMAGE2.2

(http://arch.rivm.nl/image/). Standard deviations are calculated from ' $n$ ' models. The WHO recommended SOMO35 is based on the exceedance of 35 ppbv of the daily maximum of an 8-hour running average ozone volume mixing ratio.

\begin{tabular}{|c|c|c|c|c|c|}
\hline Region & $\begin{array}{l}\mathrm{O}_{3} \\
2000 \\
\mathrm{n}=24 / 17\end{array}$ & $\begin{array}{l}\mathrm{PO}_{3} \\
\mathrm{CLE} 2030- \\
\mathrm{B} 2000 \\
\mathrm{n}=22 / 14\end{array}$ & $\begin{array}{l}?_{3} \\
\text { MFR2030 } \\
-\mathrm{B} 2000 \\
\mathrm{n}=19 / 14\end{array}$ & $\begin{array}{l}\mathrm{PO}_{3} \\
\mathrm{~A} 22_{2030-} \\
\mathrm{B} 2000 \\
\mathrm{n}=18 / 14\end{array}$ & $\begin{array}{l}?_{3} \\
\mathrm{CLE} 2030 \mathrm{C} \\
-\mathrm{CLE} 2030 \\
\mathrm{n}=9\end{array}$ \\
\hline USA & $\begin{array}{l}38.7 \pm 4.9 \\
4145 \pm 1378\end{array}$ & $\begin{array}{l}1.3 \pm 2.4 \\
583 \pm 280\end{array}$ & $\begin{array}{l}-4.9 \pm 1.8 \\
-1788 \pm 525\end{array}$ & $\begin{array}{c}4.8 \pm 4.5 \\
1911 \pm 797\end{array}$ & $-0.4 \pm 1.2$ \\
\hline $\begin{array}{l}\text { South } \\
\text { America }\end{array}$ & $\begin{array}{l}27.9 \pm 4.7 \\
1681 \pm 865\end{array}$ & $\begin{array}{l}0.5 \pm 2.0 \\
140 \pm 74\end{array}$ & $\begin{array}{l}-2.4 \pm 2.3 \\
-231 \pm 106\end{array}$ & $\begin{array}{l}5.7 \pm 2.7 \\
1247 \pm 597\end{array}$ & $-0.5 \pm 0.8$ \\
\hline $\begin{array}{l}\text { Southern } \\
\text { Africa }\end{array}$ & $\begin{array}{l}34.8 \pm 5.0 \\
3207 \pm 1304\end{array}$ & $\begin{array}{l}1.4 \pm 3.9 \\
553 \pm 190\end{array}$ & $\begin{array}{l}-2.5 \pm 4.5 \\
-332 \pm 126\end{array}$ & $\begin{array}{c}7.0 \pm 4.2 \\
2084 \pm 666\end{array}$ & $-0.4 \pm 0.7$ \\
\hline OECD Europe & $\begin{array}{l}36.6 \pm 4.2 \\
3056 \pm 1084\end{array}$ & $\begin{array}{l}1.8 \pm 1.5 \\
384 \pm 335\end{array}$ & $\begin{array}{l}-2.8 \pm 1.1 \\
-1071 \pm 292\end{array}$ & $\begin{array}{c}3.9 \pm 3.8 \\
1417 \pm 823\end{array}$ & $-0.4 \pm 0.7$ \\
\hline Middle East & $\begin{array}{l}43.5 \pm 6.4 \\
5388 \pm 1917\end{array}$ & $\begin{array}{l}1.7 \pm 2.4 \\
766 \pm 401\end{array}$ & $\begin{array}{l}-6.6 \pm 2.2 \\
-2195 \pm 668\end{array}$ & $\begin{array}{c}8.7 \pm 6.0 \\
3692 \pm 1523\end{array}$ & $-0.6 \pm 0.9$ \\
\hline South Asia & $\begin{array}{l}45.0 \pm 6.9 \\
6093 \pm 2266\end{array}$ & $\begin{array}{l}7.2 \pm 1.9 \\
3094 \pm 791\end{array}$ & $\begin{array}{l}-5.9 \pm 1.6 \\
-1976 \pm 560\end{array}$ & $\begin{array}{c}11.8 \pm 4.3 \\
4914 \pm 1435\end{array}$ & $-0.7 \pm 0.9$ \\
\hline $\begin{array}{l}\text { South East } \\
\text { Asia }\end{array}$ & $\begin{array}{l}31.5 \pm 4.4 \\
2096 \pm 937\end{array}$ & $\begin{array}{l}3.8 \pm 0.7 \\
945 \pm 329\end{array}$ & $\begin{array}{l}-3.6 \pm 0.5 \\
-703 \pm 276\end{array}$ & $\begin{array}{c}7.7 \pm 1.8 \\
2222 \pm 563\end{array}$ & $-0.6 \pm 1.0$ \\
\hline $\begin{array}{l}\text { Northern } \\
\text { Hemisphere }\end{array}$ & $\begin{array}{l}33.7 \pm 3.8 \\
2336 \pm 950\end{array}$ & $\begin{array}{l}2.3 \pm 0.5 \\
615 \pm 254\end{array}$ & $\begin{array}{l}-2.9 \pm 0.6 \\
-786 \pm 208\end{array}$ & $\begin{array}{l}5.9 \pm 2.1 \\
1738 \pm 704\end{array}$ & $-0.8 \pm 0.7$ \\
\hline $\begin{array}{l}\text { Southern } \\
\text { Hemisphere }\end{array}$ & $\begin{array}{l}23.7 \pm 3.7 \\
486 \pm 330\end{array}$ & $\begin{array}{l}0.6 \pm 2.1 \\
111 \pm 85\end{array}$ & $\begin{array}{l}-1.7 \pm 2.3 \\
-79 \pm 55\end{array}$ & $\begin{array}{r}2.7 \pm 2.6 \\
394 \pm 229\end{array}$ & $-0.7 \pm 0.6$ \\
\hline World & $\begin{array}{l}28.7 \pm 3.6 \\
1411 \pm 608\end{array}$ & $\begin{array}{l}1.5 \pm 1.23 \\
63 \pm 160\end{array}$ & $\begin{array}{l}-2.3 \pm 1.1 \\
-433 \pm 118\end{array}$ & $\begin{array}{c}4.3 \pm 2.2 \\
1066 \pm 426\end{array}$ & $-0.8 \pm 0.6$ \\
\hline
\end{tabular}


Figure 1: (a) Ozone in the year 2000; and the ozone differences between scenarios (b) CLE, (c) MFR, (d) A2 with 2000 and (e) the impact of climate change comparing CLEc and CLE. Differences are based on the averaged difference of individual model simulation. Regionally averaged measurements (upper: mean, lower left mean $+1 \mathrm{~s}$, lower right mean-1 s) are given in the circles.

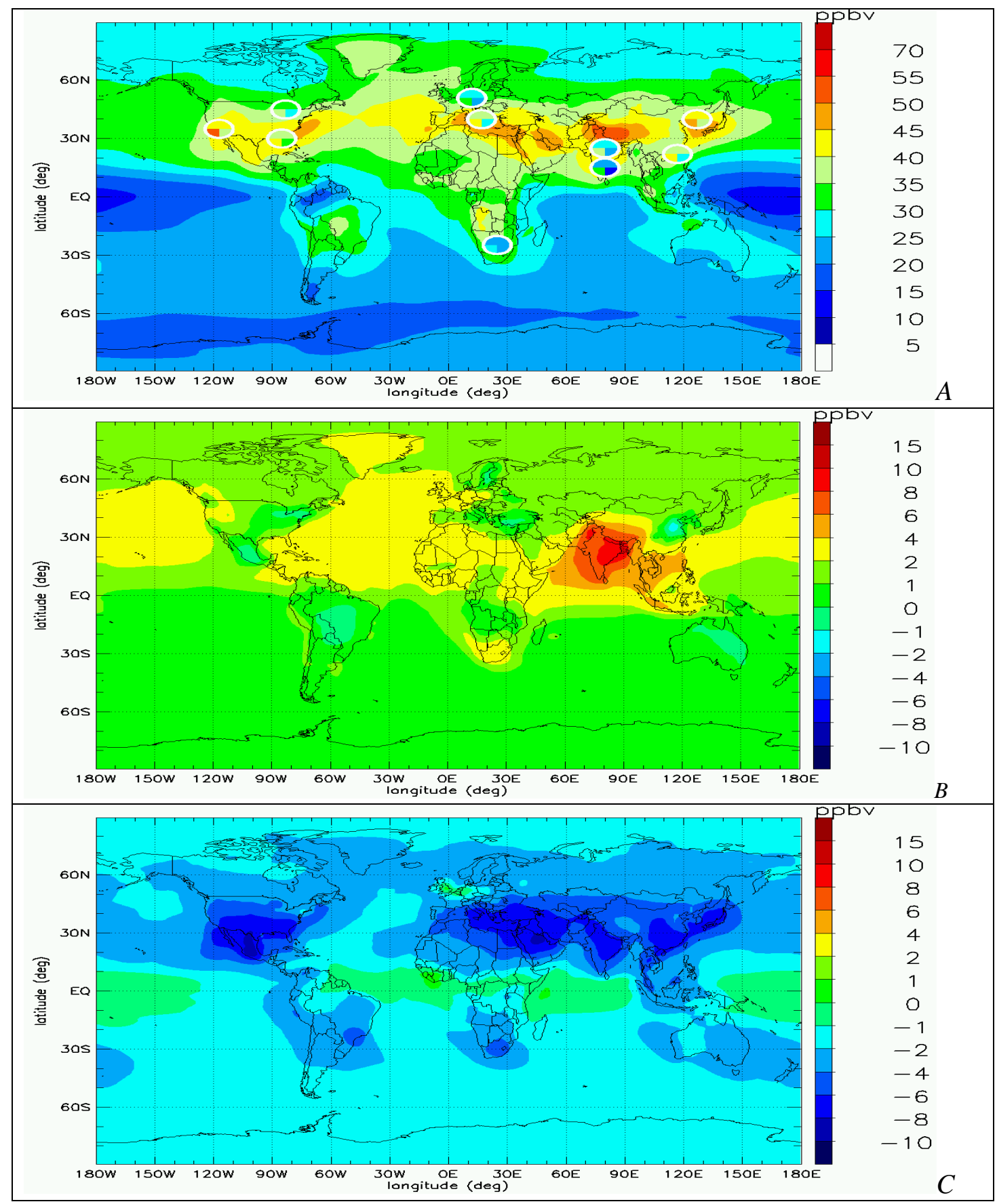




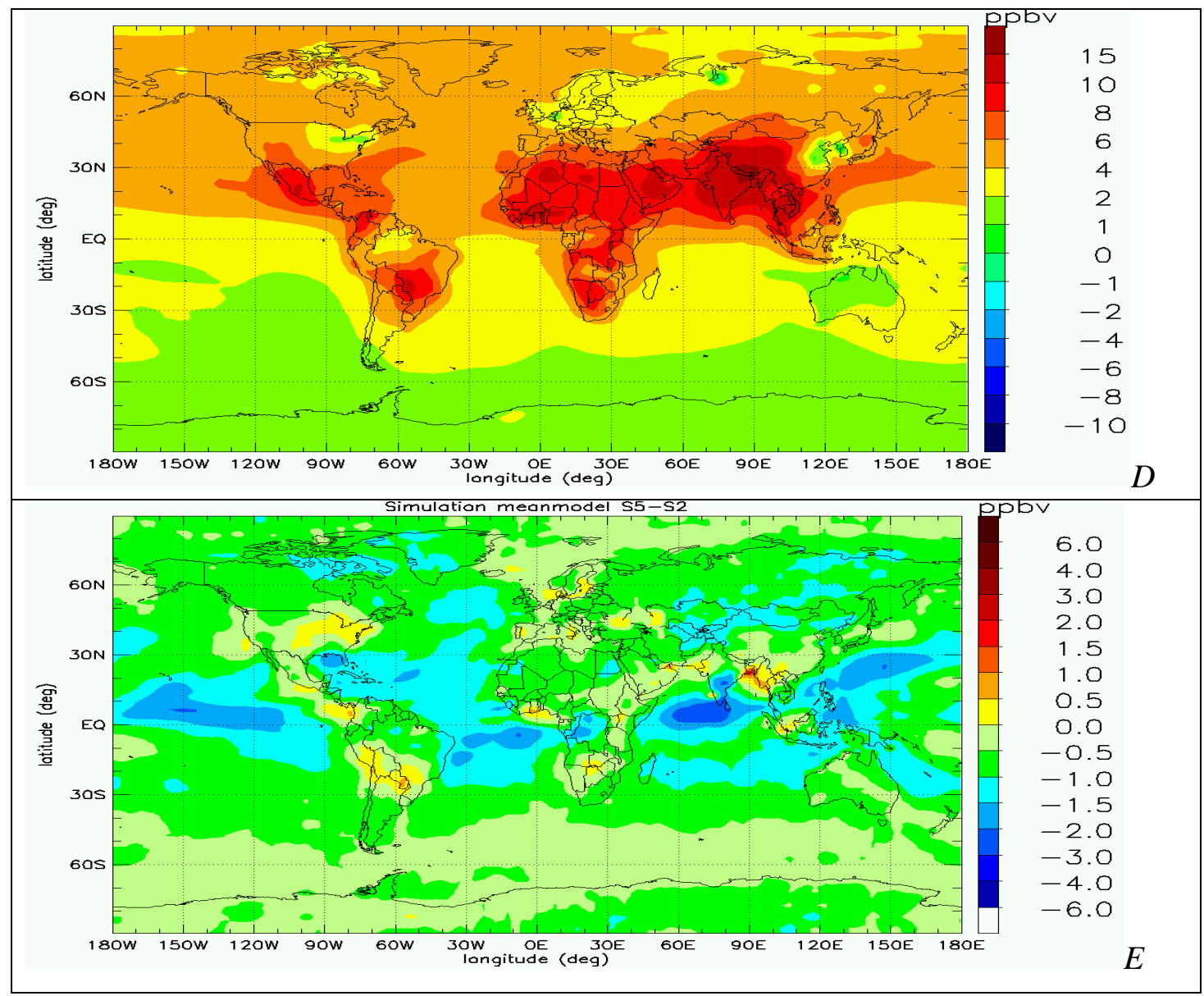


Figure 2: SOMO35 [ppbv days] (a) in the year 2000; (b) 2030 CLE; (c) 2030 MFR and (d) A2. SOMO35 is based on the daily maximum of an 8 hours moving average ozone volume mixing ratio subtracted by 35 ppbv.

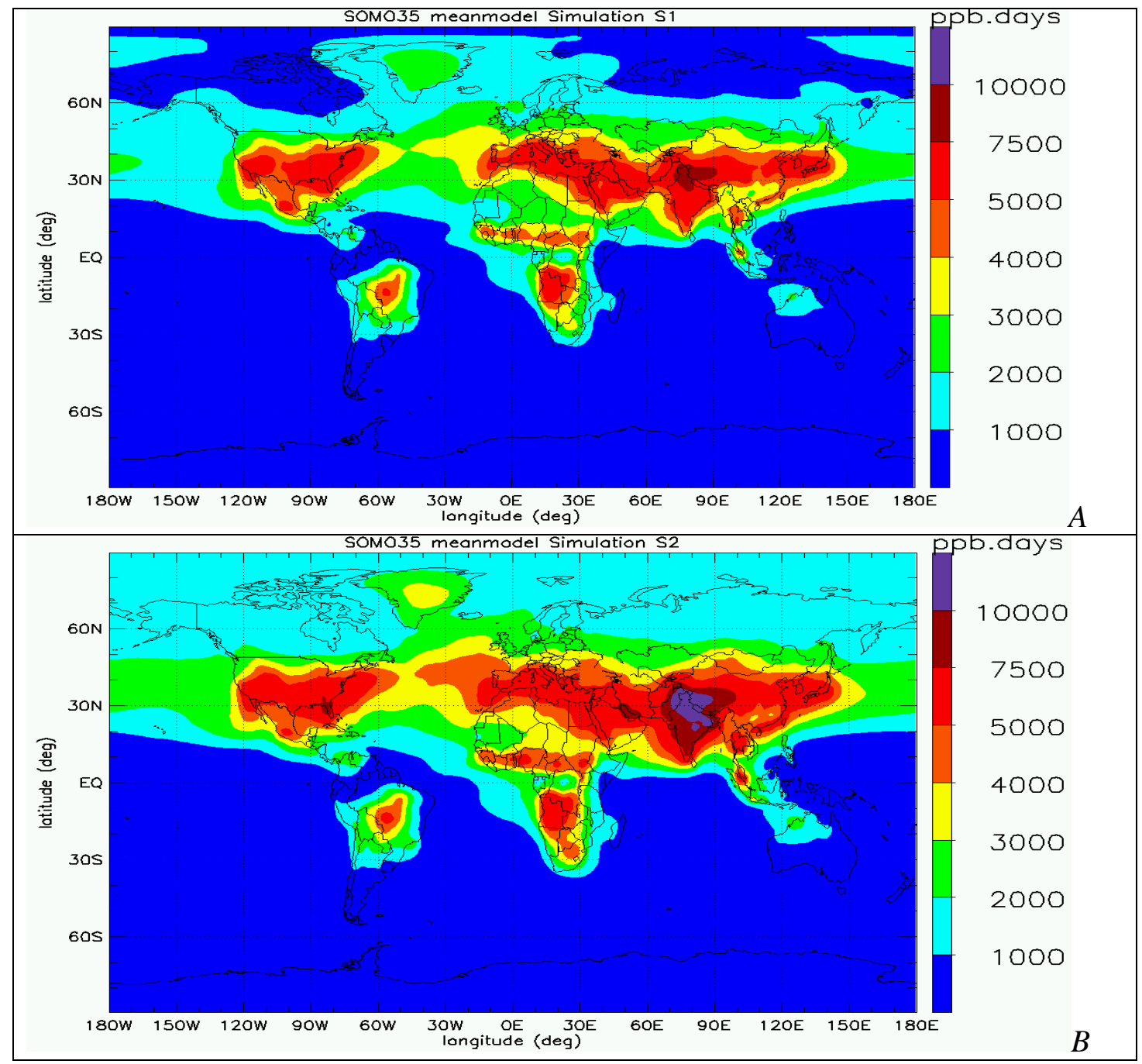




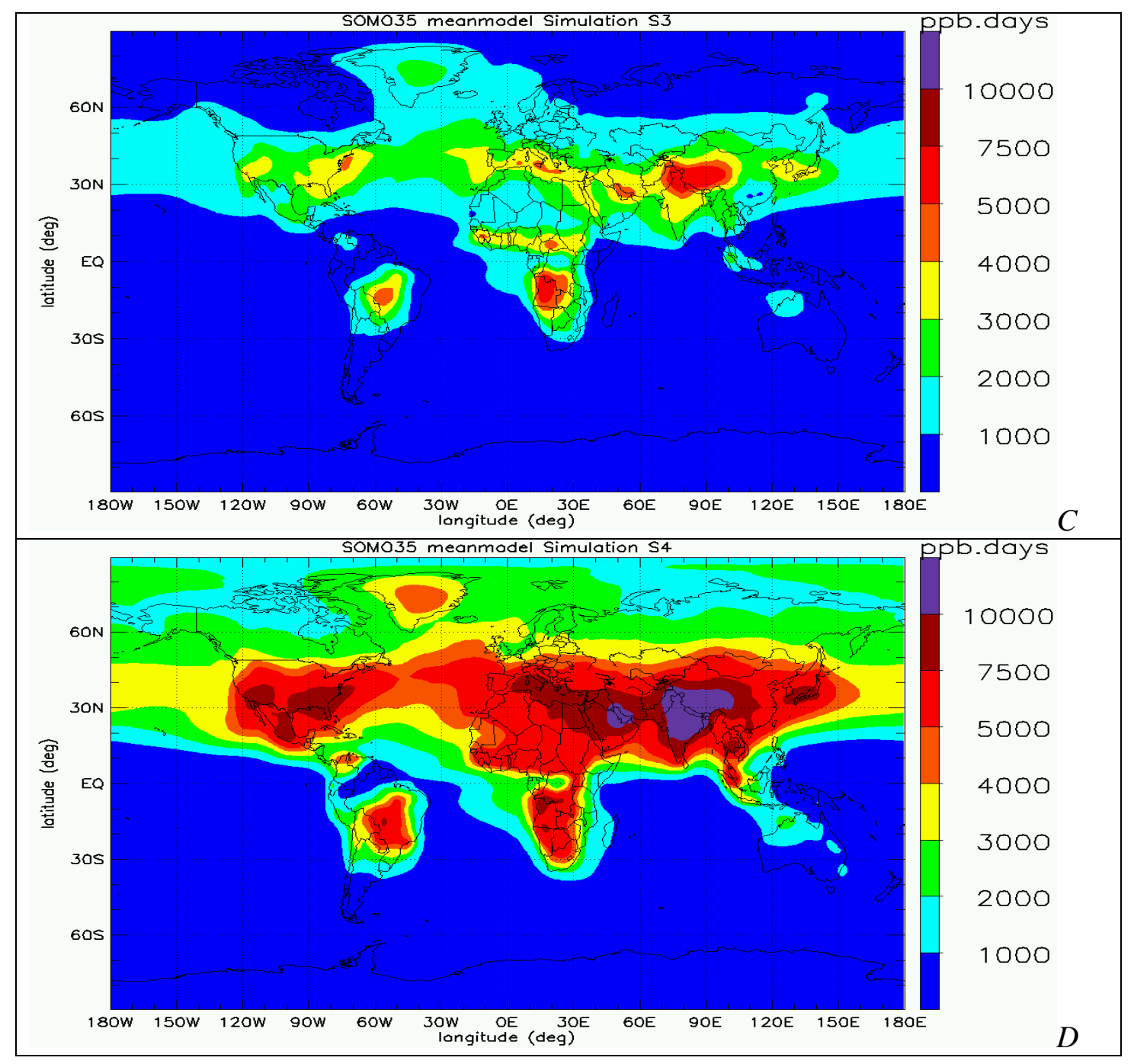


Figure 3: $\mathrm{NO}_{\mathrm{y}}$ total deposition averaged for 22 models $\left[\mathrm{mgNm}^{-2} \mathrm{yr}^{-1}\right]$ in (a) 2000 (b) CLE 2030 (c), MFR 2030 (d) A2 2030 ; and (e) total reactive nitrogen (=NO $\mathrm{O}_{\mathrm{y}}+\mathrm{NH}_{\mathrm{x}}$ ) deposition $\left[\mathrm{mgNm}^{-2} \mathrm{yr}^{-1}\right]$ in 2000.

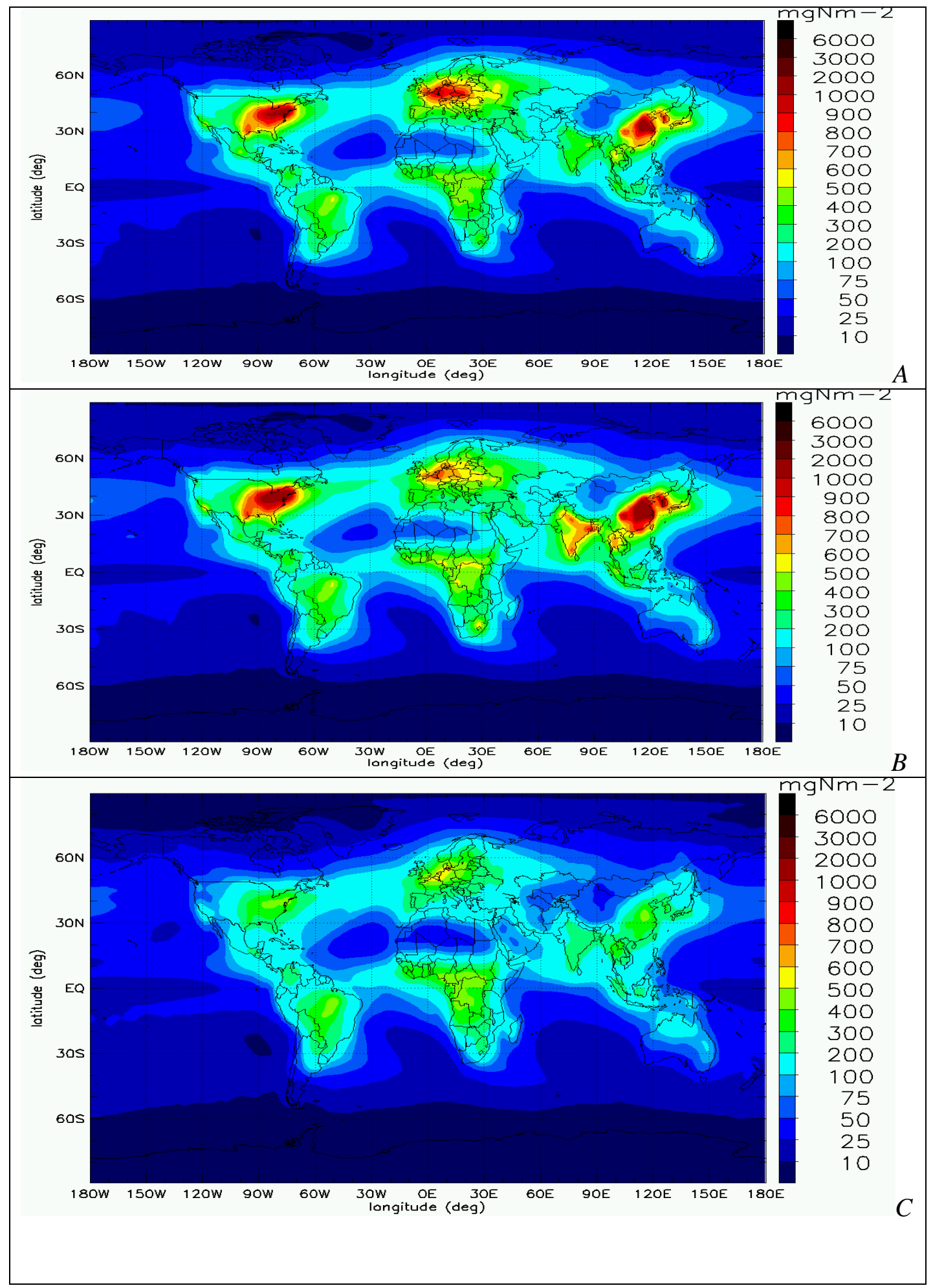




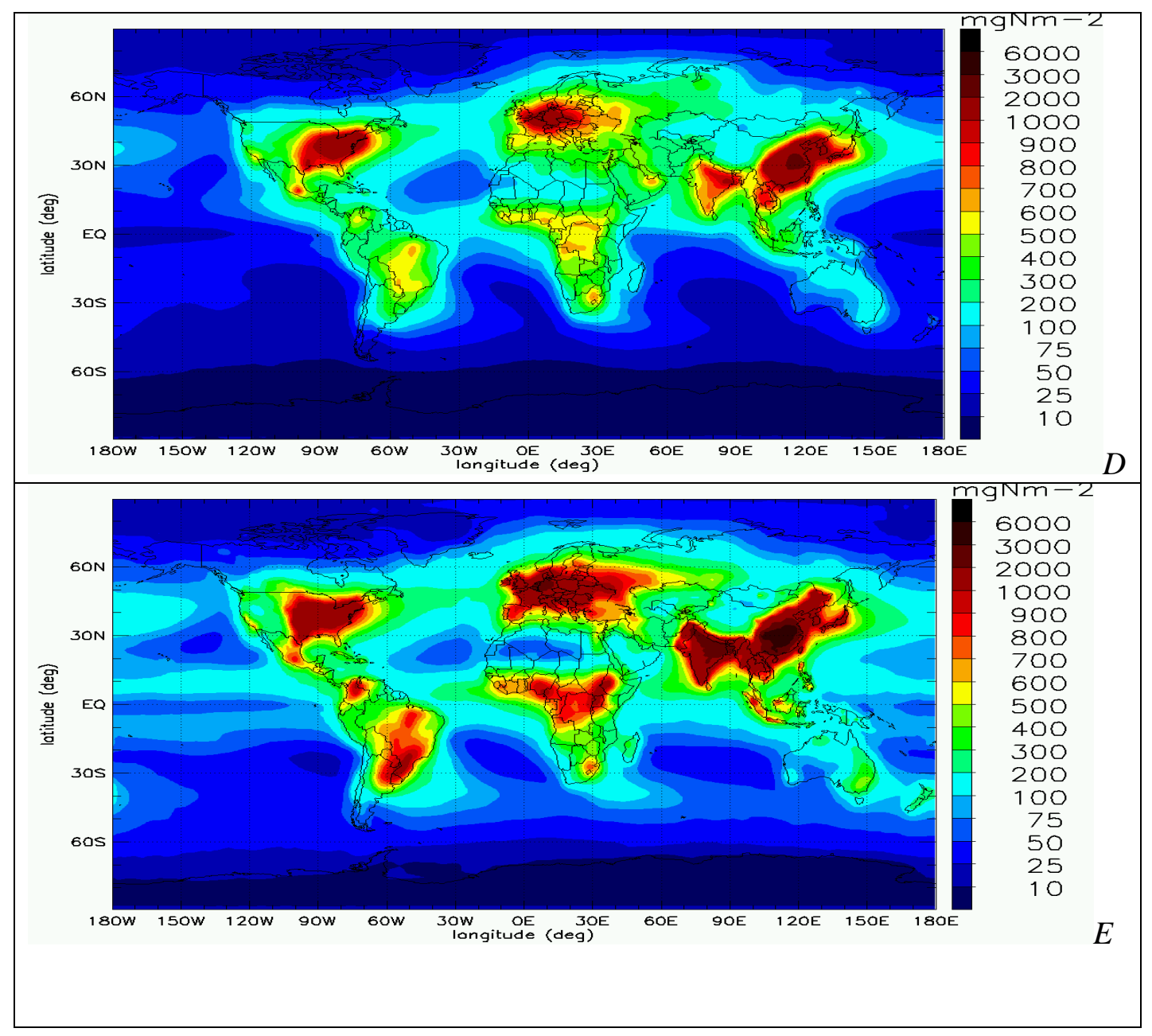


Figure 4: (a) Modelled and (b) GOME measured annual average $\mathrm{NO}_{2}$ columns for the year 2000. Modelled data represents an average of 17 models, and the GOME retrieval is an average of three retrieval products. For a consistent comparison, the data in both cases have been smoothed to a horizontal resolution of $5^{\circ} \times 5^{\circ}$.

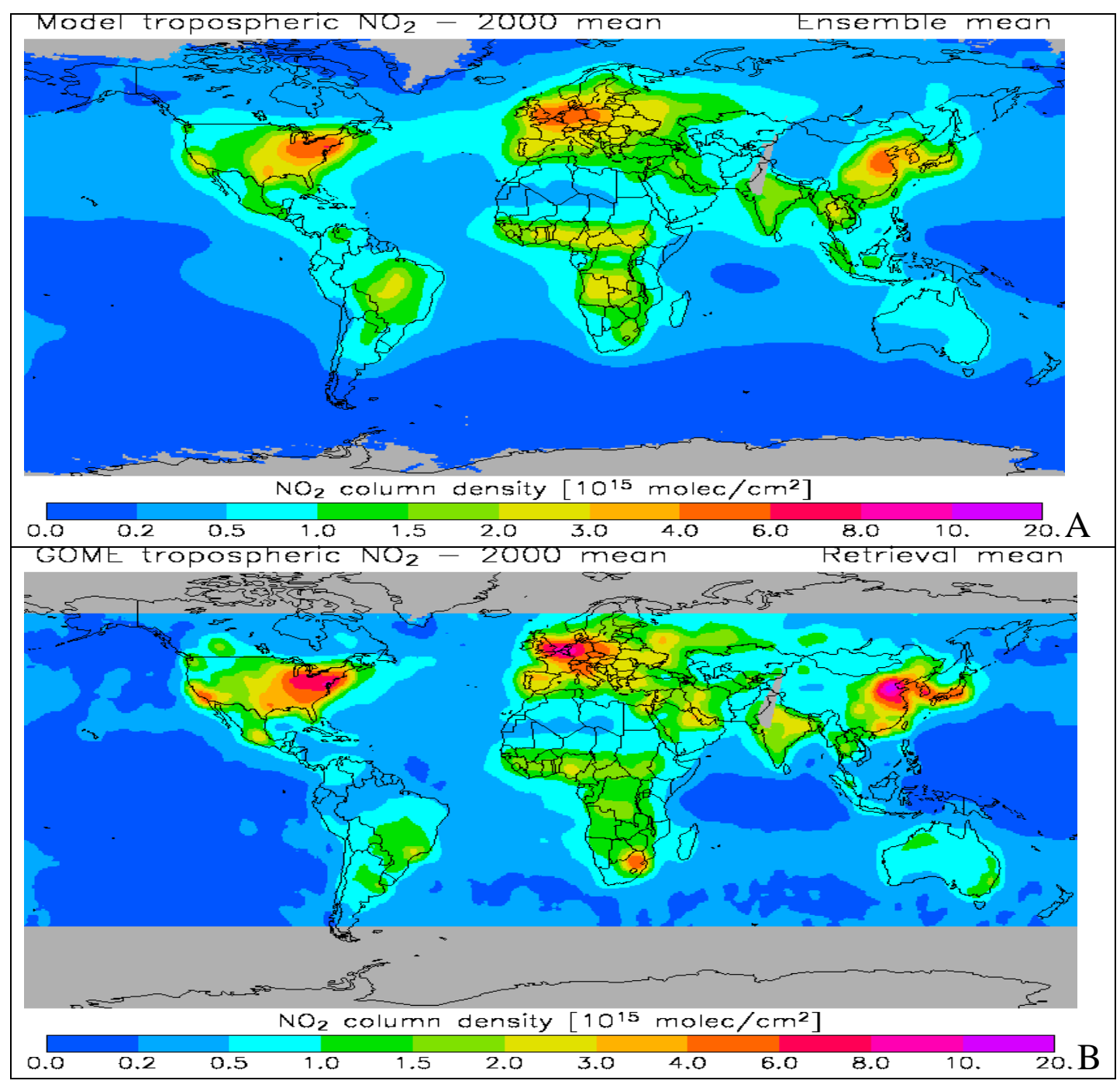

